\title{
Heterologous expression of AHL lactonase AiiK by Lactobacillus casei MCJ 1 with great quorum quenching ability against Aeromonas hydrophila $\mathrm{AH}-1$ and $\mathrm{AH}-4$
}

Weiwei Dong ${ }^{1}$, Yuyuan Cai ${ }^{1}$, Zhilong Xu', Biao Fu' ${ }^{1}$, Qitong Chen ${ }^{1}$, Yuxin Cui ${ }^{1}$, Zhiyong Ruan ${ }^{2}$, Yunxiang Liang ${ }^{1}$, Nan Peng ${ }^{1}$ and Shumiao Zhao ${ }^{1 *}$ (i)

\begin{abstract}
Background: Nowadays, microbial infections have caused increasing economic losses in aquaculture industry and deteriorated worldwide environments. Many of these infections are caused by opportunistic pathogens through cell-density mediated quorum sensing (QS). The disruption of QS, known as quorum quenching (QQ), is an effective and promising way to prevent and control pathogens, driving it be the potential bio-control agents. In our previous studies, AHL lactonase AiiK was identified with many characteristics, and constitutive expression vector pELX1 was constructed to express heterologous proteins in Lactobacillus casei MCJ $\triangle 1$ (L. casei MCJ $\triangle 1$ ). In this study, recombinant strain pELCW-aiiK/L. casei MCJA1 (LCAiiK) and wild-type Aeromonas hydrophila (A. hydrophila) were co-cultured to test the QQ ability of LCAiiK against $A$. hydrophila.

Results: A cell wall-associated expression vector pELCW for L. casei MCJ 1 was constructed. Localization assays revealed that the expressed AiiK was anchored at the surface layer of $L C A$ iiK via vector $p E L C W$-aiiK. LCAiiK $\left(O_{600}=0.5\right)$ degraded $24.13 \mu \mathrm{M}$ of $\mathrm{C}_{6}-\mathrm{HSL}$ at $2 \mathrm{~h}, 40.99 \mu \mathrm{M}$ of $\mathrm{C}_{6}-\mathrm{HSL}$ at $12 \mathrm{~h}$, and $46.63 \mu \mathrm{M}$ of $\mathrm{C}_{6}-\mathrm{HSL}$ at $24 \mathrm{~h}$. Over $50 \%$ LCAiiK cells maintained the pELCW-aiiK plasmid after 15 generations of cultivation without erythromycin. Furthermore, LCAiiK inhibited the swimming motility, extracellular proteolytic activity, haemolytic activity and biofilm formation of $A$. hydrophila $\mathrm{AH}-1$ and $\mathrm{AH}-4$.
\end{abstract}

Conclusion: The AHL lactonase AiiK is firstly and constitutively expressed at the surface layer of L. casei MCJ $\triangle 1$. LCAiiK displayed considerable AHL lactonase activity and great $\mathrm{QQ}$ abilities against $\mathrm{A}$. hydrophila $\mathrm{AH}-1$ and $\mathrm{AH}-4$ by attenuating their QS processes instead of killing them. Therefore, the LCAiiK can be exploited as an anti-pathogenic drug or a bio-control agent to control the AHL-mediated QS of pathogenic bacteria.

Keywords: Quorum sensing, Quorum quenching, AHL lactonase AiiK, Lactobacillus casei MCJA1, Aeromonas hydrophila

\footnotetext{
*Correspondence: shumiaozhao@mail.hzau.edu.cn

${ }^{1}$ State Key Laboratory of Agricultural Microbiology and College

of Life Science and Technology, Huazhong Agricultural University, Wuhan 430070, China

Full list of author information is available at the end of the article
}

\begin{abstract}
Introduction
Microbial infections have caused increasing economic losses in aquaculture industry and deteriorated worldwide environments year by year [1]. The acute hemorrhagic septicemia in fish and diarrhea in human caused by microbial infections are reported frequently [2-5].
\end{abstract}

(c) The Author(s) 2020. This article is licensed under a Creative Commons Attribution 4.0 International License, which permits use, sharing, adaptation, distribution and reproduction in any medium or format, as long as you give appropriate credit to the original author(s) and the source, provide a link to the Creative Commons licence, and indicate if changes were made. The images or other third party material in this article are included in the article's Creative Commons licence, unless indicated otherwise in a credit line to the material. If material is not included in the article's Creative Commons licence and your intended use is not permitted by statutory regulation or exceeds the permitted use, you will need to obtain permission directly from the copyright holder. To view a copy of this licence, visit http://creativeco mmons.org/licenses/by/4.0/. The Creative Commons Public Domain Dedication waiver (http://creativecommons.org/publicdomain/ zero/1.0/) applies to the data made available in this article, unless otherwise stated in a credit line to the data. 
These symptoms are mainly caused by a kind of gramnegative opportunistic pathogens [3-5]. Aeromonas hydrophila (A. hydrophila) is a representative gramnegative opportunistic pathogen, ubiquitous in fresh and estuarine water, and can infect fish, crabs, shrimps, and even humans $[4,6]$. A. hydrophila can also cause various symptoms including tissue swelling, necrosis, and ulceration in fish [7]. The bacterial infections in fish and human depend on the cell-density mediated system termed quorum sensing (QS) [6].

QS, a cell-to-cell communication mechanism in bacteria, coordinates the expression of specialized structural gene sets via specific receptors-sensing signal molecules when bacteria present at high cell densities $[8,9]$. The $N$-Acyl homoserine lactone (AHL), a common and important QS signal molecule in gram-negative bacteria, consists of a homoserine lactone and an acyl side chain of four or more carbon atoms. AHL-mediated QS traits encompass virulence factor production, swarming motility, biofilm maturation, and so on, which impart a significant advantage in survival of bacterial populations [10-12].

AHL-mediated QS triggers the expression of potential virulence and pathogenicity factors, including production of cytotoxic enterotoxin, exoprotease, lipase and hemolysin, shifting of swarming motility, and formation of biofilm in A. hydrophila $[6,13]$. The biofilm formation of $A$. hydrophila stimulates strong resistance to multiple antibiotics [14]. Furthermore, virulence factors and swarming motility associated with QS make the diseases and infections caused by $A$. hydrophila hard to be cured [14]. However, finding new and effective antibiotics is harder, and thus therapies for controlling the QS-mediated pathogenicity without causing the emergence of resistance are promising alternatives $[15,16]$. The disruption of QS, known as quorum quenching (QQ), is of great potential in alleviating the detrimental symptoms caused by QS-mediated pathogenic events, so it could be applied as a bio-control measure for pathogenic bacterial prevention and control $[9,17-20]$.

In recent years, four QQ approaches have been employed to inactivate the signal molecules and alleviate the symptoms of bacterial infections caused by QS: (1) using the purified QQ enzymes, (2) expressing QQ enzymes in pathogenic bacteria, (3) isolating and identifying new QQ strains, and 4) constructing recombinant QQ strains (Table 1). In the first case, AHL lactonases AidP [9], MomL [17], AiiK [18], RmmL [19], AiiA QSI-1 [20], and AiiA $_{\mathrm{B} 546}$ [21] were expressed by Escherichia coli or Pichia pastoris, purified and used to ease the pathogenicity of different pathogens. The purified QQ enzymes functioned very well; however, the purification was complicated and the cost for purification was high. The purified AHL lactonases had poor resistance to environment when applied in a real situation. In the second case, AHL lactonases AiiA [22], AiiM [23], AttM [24], and HqiA [25] were expressed in different pathogens, and their pathogenicity decreased. This approach occurred only under ideal research conditions, because pathogens are difficult to be modified in true situation. In the third case, Bacillus licheniformis T-1 isolated from freshwater was found to have reduced the pathogenicity of $A$. hydrophila cb15 [7]. This was due to the presence of QQ enzyme gene in the isolated B. licheniformis T-1; however, it is very difficult to isolate a strain with great AHL lactonase activity because of lacking suitable and efficient screening methods. In the last case, Zhang et al. constructed a recombinant QQ strain $B b M o m L$, and it significantly reduced the secretion of pathogenic factors and the pathogenicity of $P$. carotovorum subsp. carotovorum and Pseudomonas aeruginosa PAO1 [26]. After the recombinant QQ strain was constructed, it was applied directly against pathogens without further purification steps. Although most previous studies have focused on applying purified QQ enzymes or expressing QQ enzymes in pathogenic bacteria to inactivate the AHLs, little work has been done on constructing a recombinant QQ strain expressing the AHL lactonase on its surface to directly attenuate the symptoms caused by QS.

In our previous studies, a constitutive expression vector pELX1 was constructed and used to intracellularly express heterologous proteins in Lactobacillus casei MCJ $\Delta 1$ (L. casei MCJ $\Delta 1$ ) [27]. AiiK, identified as an AHL lactonase from Kurthia huakuii LAM0618 ${ }^{\mathrm{T}}(K$. huakuii LAM0618 ${ }^{\mathrm{T}}$ ), showed characteristics of efficient degradation of AHLs, variable substrate spectrum, suitable thermostability, and great protease-resistance [18]. In the present study, in order to express the AiiK at surface layer of $L$. casei MCJ $\Delta 1$, plasmid pELCW-aiiK was constructed and transformed into $L$. casei $\mathrm{MCJ} \Delta 1$. The recombinant strain pELCW-aiiK/L. casei MCJ $\Delta 1$ (LcAiiK) was co-cultured separately with $A$. hydrophila $\mathrm{AH}-1$ and $\mathrm{AH}-4$ to test its QQ ability against $A$. hydrophila, an opportunistic pathogen isolated from dead grass carp. $L c$ AiiK attenuated the production of virulence factors and inhibited the swimming activity and biofilm formation of A. hydrophila.

\section{Materials and methods}

\section{Bacterial strains and growth conditions}

Strain $K$. huakuii LAM0618 ${ }^{\mathrm{T}}$ was cultured in tryptic soy broth (TSB) at $30{ }^{\circ} \mathrm{C}$ with shaking. All E. coli strains were propagated in Luria-Bertani (LB) medium at $37^{\circ} \mathrm{C}$ and $180 \mathrm{rpm}$. Strain L. casei MCJ $\Delta 1$ was fostered in Man-Rogosa-Sharpe (MRS, tryptone $10.0 \mathrm{~g} / \mathrm{L}$, yeast extract $4.0 \mathrm{~g} / \mathrm{L}$, glucose $20.0 \mathrm{~g} / \mathrm{L}$, beef extract $8.0 \mathrm{~g} / \mathrm{L}$, 


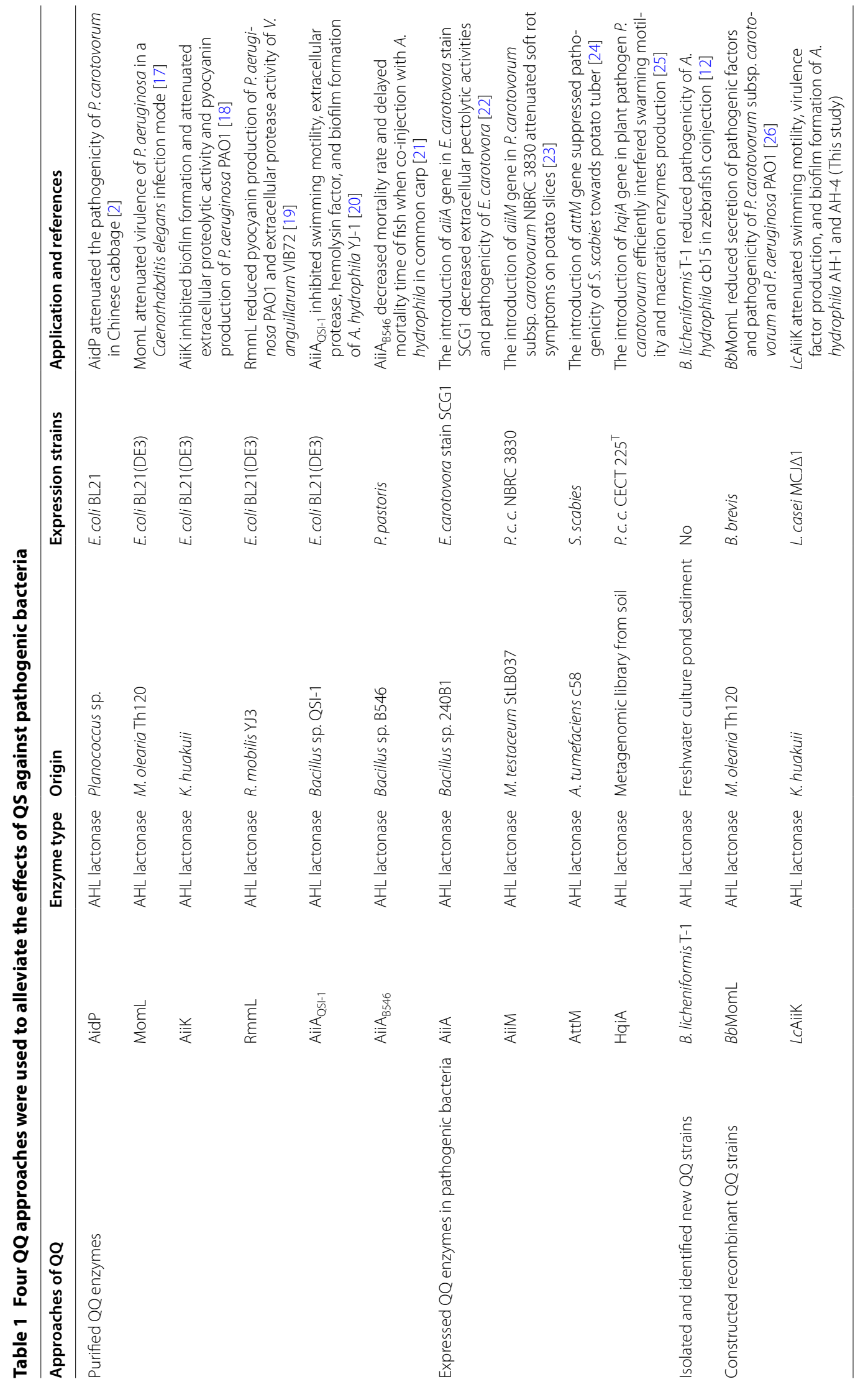


$\mathrm{NaAc} \cdot 3 \mathrm{H}_{2} \mathrm{O} 8.3 \mathrm{~g} / \mathrm{L}$, Tween $-801.0 \mathrm{~mL} / \mathrm{L}$, triammonium citrate $2.0 \mathrm{~g} / \mathrm{L}, \mathrm{K}_{2} \mathrm{HPO}_{4} \cdot 3 \mathrm{H}_{2} \mathrm{O} 2.62 \mathrm{~g} / \mathrm{L}, \mathrm{MgSO}_{4} \cdot 7 \mathrm{H}_{2} \mathrm{O}$ $\left.0.41 \mathrm{~g} / \mathrm{L}, \mathrm{MnSO}_{4} \cdot \mathrm{H}_{2} \mathrm{O} 0.056 \mathrm{~g} / \mathrm{L}, \mathrm{pH} 6.8\right)$ broth at $37^{\circ} \mathrm{C}$. Divalent metal ions-free MRS (DMIF-MRS, tryptone $10.0 \mathrm{~g} / \mathrm{L}$, yeast extract $4.0 \mathrm{~g} / \mathrm{L}$, glucose $20.0 \mathrm{~g} / \mathrm{L}$, beef extract $8.0 \mathrm{~g} / \mathrm{L}, \mathrm{NaAc} \cdot 3 \mathrm{H}_{2} \mathrm{O} 8.3 \mathrm{~g} / \mathrm{L}$, Tween-80 $1.0 \mathrm{~mL} / \mathrm{L}$, triammonium citrate $2.0 \mathrm{~g} / \mathrm{L}, \mathrm{K}_{2} \mathrm{HPO}_{4} \cdot 3 \mathrm{H}_{2} \mathrm{O}$ $2.62 \mathrm{~g} / \mathrm{L}, \mathrm{pH} 6.8$ ) was used to test the effects of divalent metal ions on AHL lactonase activity of LcAiiK. A reporter strain Chromobacterium violaceum CV026 was grown in LB medium at $30{ }^{\circ} \mathrm{C}$ and $180 \mathrm{rpm}$. $A$. hydrophila AH-1 and A. hydrophila AH-4 (16S rDNA sequences showed in supplementary material), isolated from dead grass carp (Ctenopharyngodon idellus), were proliferated in nutrient broth (NB, peptone $10.0 \mathrm{~g} / \mathrm{L}$, beef extract powder $3.0 \mathrm{~g} / \mathrm{L}$, and $\mathrm{NaCl} 5.0 \mathrm{~g} / \mathrm{L}$ ) at $30^{\circ} \mathrm{C}$ and $180 \mathrm{rpm}$. Antibiotics were added to the medium when required: ampicillin $(100 \mu \mathrm{g} / \mathrm{mL})$ for $E$. coli, kanamycin $(50 \mu \mathrm{g} / \mathrm{mL})$ for C. violaceum CV026, and erythromycin $(50 \mu \mathrm{g} / \mathrm{mL})$ for recombinant L. casei MCJ $\Delta 1$. Strains and plasmids used in this study are listed in Table 2.

\section{Construction of expression vectors $\mathrm{pELCW}$ and $\mathrm{pELCW}$-aiiK} The expression vector pELCW was constructed based on pELX1 [27]. The NlpC gene encoding a cell wallassociated protein (accession: WP_022667204, surface layer protein) was synthesized and inserted into pUC55 (pUC55-NlpC was constructed by BGI company, Shanghai, China). Then the obtained plasmid pUC55-NlpC was used as a template to amplify the $N l p C$ gene using FastPfu DNA polymerase (TransGen Biotech, Beijing, China) and $N l p C$-F-SOE and $N l p C-\mathrm{R}$ primers (PCR1,

Table 2 Bacterial strains and plasmids

\begin{tabular}{|c|c|c|}
\hline Strain or plasmid & Description & Reference or source \\
\hline \multicolumn{3}{|l|}{ Strains } \\
\hline Kurthia huakuii LAM0618 ${ }^{\top}$ & Wild type & ACCC 06121 \\
\hline Escherichia coli DH5a & $\begin{array}{l}\lambda^{-} \text {中80dlacZLM15 } \triangle \text { (lacZYA-argF) U169 recA1 endA hsdR17 }\left(\mathrm{r}_{\mathrm{K}}^{-}\right. \\
\left.\mathrm{m}_{\mathrm{K}}^{-}\right) \text {supE44 thi-1 gyrA relA1 }\end{array}$ & Tiangen \\
\hline Lactobacillus casei MCJ $\triangle 1$ & pMC11-cured strain & Chen et al. (2014) [27] \\
\hline Chromobacterium violaceum CV026 & ATCC 31532 derivative, cvil:::Tn5xylE Kmr, Smr & From Dr. Guishan Zhang \\
\hline Aeromonas hydrophila $\mathrm{AH}-1$ & Wild type & Isolated from dead grass carp \\
\hline Aeromonas hydrophila $\mathrm{AH}-4$ & Wild type & Isolated from dead grass carp \\
\hline \multicolumn{3}{|l|}{ Plasmids } \\
\hline pELX1 & Expression vector, $\mathrm{Amp}^{r}$ & Chen et al. (2014) [27] \\
\hline pUC55-NIpC & pUC55 containing NIpC gene & Constructed by BGl \\
\hline pELCW & Expression vector, $\mathrm{Amp}^{\mathrm{r}}$ & This study \\
\hline pELCW-aiik & pELCW containing aiik gene & This study \\
\hline
\end{tabular}

Table 3 Specific PCR used in this study

\begin{tabular}{|c|c|c|}
\hline Genes & Primers & Amplification parameters \\
\hline \multirow[t]{2}{*}{ NHM(PCR1) } & $\begin{array}{l}\text { NIpC-F-SOE: CAAGGAGGAAAAGACCACATGGTAGATGCAAAG } \\
\text { AAAGTATTG }\end{array}$ & $95^{\circ} \mathrm{C}$ for $5 \mathrm{~min}, 95^{\circ} \mathrm{C}$ for $30 \mathrm{~s}, 57^{\circ} \mathrm{C}$ for $30 \mathrm{~s}$, and $72{ }^{\circ} \mathrm{C}$ for $60 \mathrm{~s}$ \\
\hline & $\begin{array}{l}\text { NIpC-R: GGAAGATCTCCATGGCTCGAGATGATGATGATGATGGTG } \\
\text { TAGTGAAGGACGAACAGC }\end{array}$ & \\
\hline \multirow[t]{2}{*}{$P_{S I P A}(P C R 2)$} & $P_{\text {slpA }}-\mathrm{F}:$ CCGGAATTCAAGCGGTAGGTG & $95^{\circ} \mathrm{C}$ for $5 \mathrm{~min}, 95^{\circ} \mathrm{C}$ for $30 \mathrm{~s}, 57^{\circ} \mathrm{C}$ for $30 \mathrm{~s}$, and $72{ }^{\circ} \mathrm{C}$ for $40 \mathrm{~s}$ \\
\hline & $\begin{array}{l}P_{\text {sIpA }}-\text { R-SOE: CAATACTTTCTTTGCATCTACCATGTGGTCTTTTCC } \\
\text { TCCTTG }\end{array}$ & \\
\hline \multirow[t]{2}{*}{$P_{s / p A^{-N H M}(S O E-P C R)}$} & $P_{\text {slpA }}-\mathrm{F}:$ CCGGAATTCAAGCGGTAGGTG & $95^{\circ} \mathrm{C}$ for $5 \mathrm{~min}, 95^{\circ} \mathrm{C}$ for $30 \mathrm{~s}, 56^{\circ} \mathrm{C}$ for $30 \mathrm{~s}$, and $72{ }^{\circ} \mathrm{C}$ for $100 \mathrm{~s}$ \\
\hline & $\begin{array}{l}\text { NIpC-R: GGAAGATCTCCATGGCTCGAGATGATGATGATGATGGTG } \\
\text { TAGTGAAGGACGACAGC }\end{array}$ & \\
\hline \multirow[t]{2}{*}{$\operatorname{aiiK}(P C R 3)$} & aiikF: GGAAGATCTATGTGTCAAAATAAAAAGTTGTAC & $95^{\circ} \mathrm{C}$ for $5 \mathrm{~min}, 95^{\circ} \mathrm{C}$ for $30 \mathrm{~s}, 54^{\circ} \mathrm{C}$ for $30 \mathrm{~s}$, and $72{ }^{\circ} \mathrm{C}$ for $60 \mathrm{~s}$ \\
\hline & aiiKR: CGGGGTACCTTATTCGTAATACCCTTCCGTTGA & \\
\hline \multirow[t]{2}{*}{ Sequencing } & EcoRI-P $P_{\text {SIpA }}-\mathrm{F}:$ CCGGGAATTCAAGCGGTAGGTGAAATATTAC & $95^{\circ} \mathrm{C}$ for $5 \mathrm{~min}, 95^{\circ} \mathrm{C}$ for $30 \mathrm{~s}, 55.5^{\circ} \mathrm{C}$ for $30 \mathrm{~s}$, and $72^{\circ} \mathrm{C}$ for $120 \mathrm{~s}$ \\
\hline & BamHI-T-R: GGCCGGATCCAGCTTGCGTTTGATTTTC & \\
\hline
\end{tabular}

His tag was marked in italics, and multiple cloning sites (MCS) were marked in bold 
Table 3). The DNA sequence coding for His tag (in italics) and partial multiple cloning sites (MCS, in bold) were included in the $N l p C-\mathrm{R}$ primer. The $N l p C$ gene, His-tag gene, and partial MCS were arranged in a row within the PCR1 product, and the PCR1 product was named as $N l p C$-His-MCS $(N H M)$ gene. Meanwhile, the $P_{s l y A}$ gene was amplified using pELX1 and FastPfu DNA polymerase with $P_{s l y A}-\mathrm{F}$ and $P_{s l y A}$-R-SOE primers (PCR2, Table 3). The splicing overlapping extension (SOE) PCR (amplification composition shown in Additional file 1: Table S1) [28] was used to fuse the $P_{s l y A}$ gene and NHM gene using $P_{s l y A}-\mathrm{F}$ and $N l p C-\mathrm{R}$ primers (Table 3). The SOE-PCR product and pELX1 vector were digested with EcoRI and $\mathrm{Bgl} \Pi$ at $37^{\circ} \mathrm{C}$ for $4 \mathrm{~h}$, and then purified by Cycle-Pure Kit (Omega Bio-Tek, USA) and Gel Purification Kit (TIANGEN, China), respectively. The digested products were linked using T4 DNA ligase (Thermo Scientific, USA) for constructing the expression plasmid pELCW.

The genomic DNA of $K$. huakuii LAM0618 ${ }^{\mathrm{T}}$ was utilized to amplify the $a i i K$ gene using the $a i i K \mathrm{~F}$ and aiiKR primers (PCR3, Table 3). The aiiK gene and pELCW vector were digested with BglП and $\mathrm{KpnI}$ at $37{ }^{\circ} \mathrm{C}$ for $4 \mathrm{~h}$, and purified as mentioned earlier. Then ligation was performed by T4 DNA ligase to form pELCW-aiiK. Both $\mathrm{pELCW}$ and $\mathrm{pELCW}$-aiiK were transformed into $E$. coli DH5 $\alpha$ for storage, and then sequenced by company BGI (Shanghai, China) with the EcoRI-P $P_{S l y A}-\mathrm{F}$ and BamHI-TR primers (Table 3).

\section{Construction of the recombinant strain of pELCW-aiiK/L. casei MCJ 1}

Competent cells of $L$. casei MCJ $\Delta 1$ were prepared based on our previous study [27]. Electrotransformation was performed as follows: $200 \mathrm{ng}$ of pELCW-aiiK or pELCW was mixed with the $80-\mu \mathrm{L}$ competent cells. The mixture was transferred into a 2-mm electroporation cuvette (Bio-Rad, USA), and then incubated on ice for $10 \mathrm{~min}$. Subsequently, the electroporation was carried out at $1500 \mathrm{~V}$ and $5 \mathrm{~ms}$ with an Eppendorf Multiporator (Eppendorf, Hamburg, Germany). After electroporation, the mixture was transferred to $920-\mu \mathrm{L}$ pre-warmed MRSS (MRS with $0.3 \mathrm{M}$ sucrose) broth, and then incubated at $37^{\circ} \mathrm{C}$ for $3 \mathrm{~h}$ for recovery. At last, the mixture was plated on MRS agar with erythromycin and incubated at $37^{\circ} \mathrm{C}$ for $48 \mathrm{~h}$ to screen for recombinant strains.

\section{Detection of AHL lactonase activity of LCAiiK}

Lactobacillus casei $\mathrm{MCJ} \Delta 1$ harboring pELCW-aiiK was inoculated into $100 \mathrm{~mL}$ of fresh MRS medium (containing erythromycin) at the ratio of $1 \%$. After incubation at $37^{\circ} \mathrm{C}$ for $20 \mathrm{~h}$, the cells were harvested by centrifugation and washed twice with $10 \mathrm{mM}$ phosphate buffer saline (PBS, pH 7.4). These washed cells were re-suspended in
$10 \mathrm{mM}$ PBS, and the suspension was subjected to detect the AHL lactonase activity. The reaction mixture $(500 \mu \mathrm{L})$ containing $L c$ AiiK cells $\left(\mathrm{OD}_{600}=5.0\right)$ and $50 \mu \mathrm{M} \mathrm{N}$-Hexanoyl-L-homoserine lactone $\left(\mathrm{C}_{6}-\mathrm{HSL}\right)$ in $10 \mathrm{mM}$ PBS (pH 7.4) was incubated at $37^{\circ} \mathrm{C}$ for $3 \mathrm{~h}$. Then, sodium dodecyl sulfate (SDS) was added into the mixture to terminate the reaction. The unreacted $\mathrm{C}_{6}$ - $\mathrm{HSL}$ was extracted based on our previous study [18]. For the negative control, $L c$ AiiK cells were replaced by pELCW/L. casei MCJ $\Delta 1(L c C W)$ cells with the other conditions being the same. For the positive control, $4 \mu \mathrm{g} / \mu \mathrm{L}$ of AiiK purified from $E$. coli BL21 (DE3) was used to replace $L c$ AiiK cells. At last, the extracted $\mathrm{C}_{6}$-HSL was detected by using the violacein generation bioassay and quantified using the high performance liquid chromatography (HPLC).

In the violacein generation bioassay, $1 \mathrm{~mL}$ overnight culture of C. violaceum CV026 was mixed well with $24 \mathrm{~mL}$ molten LB agar (1.6\%), and the mixture was poured onto the plates. After the agar solidification, a sterile filter paper disk with a diameter of $5.5 \mathrm{~mm}$ was placed on every plate. The extracted $\mathrm{C}_{6}$-HSL samples were dropped onto the filter paper discs, and the plates were incubated at $30{ }^{\circ} \mathrm{C}$ for $16 \mathrm{~h}$ to generate violacein.

In the HPLC analysis, the Agilent Eclipse Plus C18 $(4.6 \times 250 \mathrm{~mm}, 5 \mu \mathrm{m})$ column and Agilent Technologies 1200 series were employed. The extracted $\mathrm{C}_{6}$-HSL was separated at $22{ }^{\circ} \mathrm{C}$ with a constant flow rate of $0.7 \mathrm{~mL} /$ $\mathrm{min}$ in isocratic elution (acetonitrile/water $=31 / 69, \mathrm{v} / \mathrm{v}$ ) and then detected at $210 \mathrm{~nm}$.

\section{Localization assays of AiiK in LCAiiK}

The surface layer proteins are localized on the outer layer of the peptidoglycan, lysozyme can degrade the peptidoglycan of gram-positive bacterial cell wall, and release the surface layer proteins. To verify that the AiiK was expressed on the surface layer of $L c$ AiiK cells, the localization of AiiK was carried out. $L c$ AiiK cells $\left(\mathrm{OD}_{600}=0.5\right)$ were treated with lysozyme (Amresco, China) $(20 \mathrm{mg} /$ $\mathrm{mL}$ ) in $10 \mathrm{mM}$ PBS (pH 7.4) at $37^{\circ} \mathrm{C}$ for $1 \mathrm{~h}, 2 \mathrm{~h}$, and $3 \mathrm{~h}$. After incubation, the mixture was centrifuged at $12,000 \mathrm{rpm}$ for $2 \mathrm{~min}$ to collect the supernatant for detecting AHL lactonase activity. The substrate $\mathrm{C}_{6}-\mathrm{HSL}$ $(50 \mu \mathrm{M})$ was added into and incubated at $37^{\circ} \mathrm{C}$ for $12 \mathrm{~h}$. The unreacted $\mathrm{C}_{6}$-HSL was quantified using the method described above. For the positive control, the supernatant was replaced with $L c$ AiiK cells $\left(\mathrm{OD}_{600}=0.5\right)$. For the negative control, the supernatant was replaced with the same volume of lysozyme solution (lysozyme was dissolved in 10 mM PBS, pH 7.4).

\section{Characteristics of $L C A$ iiiK}

The characteristics of $L c$ AiiK were determined by detecting its AHL lactonase activity. The reaction mixture (500 
$\mu \mathrm{L})$ contained $L c$ AiiK cells $\left(\mathrm{OD}_{600}=0.5\right)$ and $\mathrm{C}_{6}-\mathrm{HSL}$ $(50 \mu \mathrm{M})$ in PBS $\left(10 \mathrm{mM}, \mathrm{pH}\right.$ 7.4). In $\mathrm{C}_{6}$-HSL degradation assay, the reaction mixture was incubated at $37{ }^{\circ} \mathrm{C}$ for 0 , $1,2,4,6,8,10,12,16,20$, and $24 \mathrm{~h}$, respectively, and the residual $\mathrm{C}_{6}$-HSL was quantified by HPLC. The optimal cell density $\left(\mathrm{OD}_{600}\right)$ of $L c$ AiiK to degrade $\mathrm{C}_{6}$-HSL was determined using different optical densities $\left(\mathrm{OD}_{600}=0.1\right.$, $0.5,1.0,2.0$, and 3.0), and the reaction mixture was incubated at $37^{\circ} \mathrm{C}$ for $12 \mathrm{~h}$. The optimal reaction temperature was determined by incubating the reaction mixture at $25{ }^{\circ} \mathrm{C}, 30{ }^{\circ} \mathrm{C}, 35{ }^{\circ} \mathrm{C}, 37{ }^{\circ} \mathrm{C}, 40{ }^{\circ} \mathrm{C}, 45{ }^{\circ} \mathrm{C}$, and $50{ }^{\circ} \mathrm{C}$. The effects of divalent metal ions on $L c$ AiiK in vivo were examined by cultivating $L c$ AiiK in DMIF-MRS broth with addition one kind of divalent metal ions $(1 \mathrm{mM}$ $\mathrm{Zn}^{2+}, 1 \mathrm{mM} \mathrm{Mg}^{2+}, 1 \mathrm{mM} \mathrm{Mn}^{2+}, 1 \mathrm{mM} \mathrm{Co}^{2+}$, and $1 \mathrm{mM}$ $\mathrm{Ni}^{2+}$ ), the cultures were incubated at $37{ }^{\circ} \mathrm{C}$ for $20 \mathrm{~h}$. After incubation, the cells were harvested and subjected to detect AHL lactonase activity. The effects of divalent metal ions on $L c$ AiiK in vitro were examined by culturing LcAiiK in DMIF-MRS broth at $37^{\circ} \mathrm{C}$ for $20 \mathrm{~h}$. After incubation, the harvested cells and one kind of divalent metal ions $\left(1 \mathrm{mM} \mathrm{Zn}^{2+}, 1 \mathrm{mM} \mathrm{Mg}^{2+}, 1 \mathrm{mM} \mathrm{Mn}^{2+}, 1 \mathrm{mM} \mathrm{Co}^{2+}\right.$, and $1 \mathrm{mM} \mathrm{Ni}^{2+}$ ) were added to detect the AHL lactonase activity.

\section{Determination of plasmid stability}

To calculate the plasmid stability of pELCW-aiiK in strain $L$. casei $M C J \Delta 1$, the $L c$ AiiK was inoculated into MRS at ratio of $1 \%$ without erythromycin for continuous passage culture of 15 generations, and every generation was propagated for $12 \mathrm{~h}$. At every generation, colonyforming units $(\mathrm{cfu})$ were determined by MRS agar plates and selective MRS agar plates ( $50 \mu \mathrm{g} / \mathrm{mL}$ erythromycin). The plasmid stability of pELCW-aiiK was calculated as the ratio of cfu number on selective MRS agar versus that on MRS agar [27]. Therefore, the plasmid stability per generation was calculated by equation:

$$
L=\sqrt[n]{\bar{x} / \bar{y}} \times 100 \%
$$

Herein, " $L$ " is plasmid stability, " $n$ " is continuous generations cultured, " $\bar{x}$ " is the average cfu numbers on selective MRS agar, and " $\bar{y}$ " is the average cfu numbers on MRS agar.

\section{Effect of LCAiiK on swimming motility in A. hydrophila}

The effect of $L c$ AiiK on swimming motility in A. hydrophila was determined based on the method described by Jahid et al. with minor modifications [6]. Fifty microliter of co-culture mixture containing $L c \mathrm{AiiK}$ at various concentrations $\left(\mathrm{OD}_{600}=0.1,0.2\right.$, and 0.4$)$ and A. hydrophila $\mathrm{AH}-1$ or $\mathrm{AH}-4\left(\mathrm{OD}_{600}=0.1\right)$ in $10 \mathrm{mM} \mathrm{PBS}(\mathrm{pH} 7.4)$ was inoculated onto the center of NA (NB with $0.3 \%$ agar) plates, and then incubated at $25{ }^{\circ} \mathrm{C}$ for $24 \mathrm{~h}$. After incubation, the diameter of strain lawn was measured. The $L c \mathrm{CW}$ cells was used as negative control, and $10 \mathrm{mM}$ PBS was used as control check (CK).

\section{Effect of LcAiiK on haemolytic activity in A. hydrophila}

Blood agar plates were utilized to evaluate the effect of LcAiiK on haemolytic activity in A. hydrophila [29]. Eighty microliter of co-culture mixture, comprising LcAiiK $\left(\mathrm{OD}_{600}=0.5\right)$ and $A$. hydrophila $\mathrm{AH}-1$ or $\mathrm{AH}-4$ $\left(\mathrm{OD}_{600}=0.1\right)$ in $10 \mathrm{mM}$ PBS (pH 7.4), was inoculated into the hole on blood agar plate and incubated at $30{ }^{\circ} \mathrm{C}$ for $24 \mathrm{~h}$. The zone of complete haemolysis was measured to assess haemolytic activity of $A$. hydrophila. The negative control and $\mathrm{CK}$ were prepared as mentioned earlier.

\section{Effect of $L C A i i K$ on extracellular proteolytic activity in $A$. hydrophila}

The effect of $L c$ AiiK on extracellular proteolytic activity in A. hydrophila was evaluated by conducting an extracellular proteolytic assay according to Bhakti et al. with modifications [30]. A. hydrophila $\mathrm{AH}-1$ or AH-4 was inoculated into fresh NB with different concentrations of LcAiiK $\left(\mathrm{OD}_{600}=0.1,0.2\right.$, and 0.4$)$, then the mixture was incubated at $30{ }^{\circ} \mathrm{C}$ and $180 \mathrm{rpm}$ for $20 \mathrm{~h}$. After incubation, the NB culture supernatant was used as the crude enzyme extract for detecting the extracellular proteolytic activity. The reaction mixture contained $250 \mu \mathrm{L}$ of supernatant and $250 \mu \mathrm{L}$ of $2 \%$ azocasein. After reacting at $30{ }^{\circ} \mathrm{C}$ for $3 \mathrm{~h}, 1.2 \mathrm{~mL} 10 \%$ trichloroacetic acid was added and centrifuged at $6000 \mathrm{~g}$ for $10 \mathrm{~min}$. Then $1.2 \mathrm{~mL}$ of supernatant was mixed with $1.0 \mathrm{~mL}$ of $1 \mathrm{M} \mathrm{NaOH}$, and the optical density was assessed at $440 \mathrm{~nm}$. The negative control and CK were prepared as mentioned earlier.

\section{Effect of $L c A$ AiiK on biofilm formation by $A$. hydrophila}

The effect of $L c$ AiiK on the biofilm formation by $A$. hydrophila was examined based on the method described by Dong et al. with some modifications [18]. About 200 $\mu \mathrm{L}$ co-culture mixture, containing $L c$ AiiK with various concentrations $\left(\mathrm{OD}_{600}=0.1,0.2\right.$, and 0.4$)$ and $A$. hydrophila $\mathrm{AH}-1$ or $\mathrm{AH}-4\left(\mathrm{OD}_{600}=0.1\right)$, was dispensed into a 96-well microtiter plate and statically incubated at $30{ }^{\circ} \mathrm{C}$ for $12 \mathrm{~h}$. After incubation, planktonic cells from the plate were transferred out gently for dilution plate count of A. hydrophila AH-1 and AH-4. The biofilm cells were washed very gently with $10 \mathrm{mM}$ PBS for three times, and then stained with $20 \mu \mathrm{L}$ of $0.2 \%$ crystal violet at $25^{\circ} \mathrm{C}$ for $15 \mathrm{~min}$. The stained biofilm cells were washed very gently with distilled water for three times. Ethanol $(100 \mu \mathrm{L}, 95 \%)$ was added to extract crystal violet, and the absorbance at 
$590 \mathrm{~nm}$ was measured. The negative control and CK were prepared as mentioned earlier.

\section{Statistical analysis}

All data were processed using Excel (version 2019) as mean \pm standard deviation (sd), and differences with $\mathrm{P}<0.05$ and $\mathrm{P}<0.01$ were deemed significant.

\section{Results}

\section{Construction of recombinant strain LCAiiK}

To construct the cell wall-associated expression vector pELCW, we inserted gene $N l p C$ at the end of promoter $P_{s l y A}$ and in the front of His-tag gene on plasmid pELX1. The $N l p C$ gene was used as a guide peptide sequence to help target protein anchor at the surface layer. The SOEPCR product ( $P_{s l y A}-N H M$ gene) (Additional file 1: Fig. S1) was inserted into pELX1 between the EcoRI and BglП sites (Fig. 1). We named the new plasmid pELCW, which was constructed from pELX1 with cell wall-associated expression function. Furthermore, the aiiK gene was inserted into pELCW between the BglП and KpnI sites (Fig. 1), generating the plasmid pELCW-aiiK (Fig. 1).
Screening of the recombinant strain by colony PCR and plasmid sequencing indicated that the pELCWaiiK/L. casei $\mathrm{MCJ} \Delta 1$ and $\mathrm{pELCW} / L$. case $\mathrm{MCJ} \Delta 1$ were constructed correctly. The recombinant strain pELCWaiiK/L. casei MCJ $\Delta 1$ was designated as $L c A i i K$ (AiiK expressed by $\underline{L}$. $\underline{\text { casei }} \mathrm{MCJ} \Delta 1$ ) whereas the recombinant strain $\mathrm{pELCW} / L$. casei $\mathrm{MCJ} \Delta 1$ was designated as $L c \mathrm{CW}$.

\section{Detection of AHL lactonase activity of LCAiiK and localization assays of AiiK in LcAiiK}

The results showed that $L c$ AiiK $\left(\mathrm{OD}_{600}=5.0\right)$ could degrade $35.18 \mu \mathrm{M} \mathrm{C}_{6}$ - $\mathrm{HSL}$ at $37^{\circ} \mathrm{C}$ within $3 \mathrm{~h}$ and $L c \mathrm{CW}$ didn't exhibit any AHL lactonase activity to $\mathrm{C}_{6}$-HSL (Fig. 2a). The purified AiiK $(4 \mu \mathrm{g} / \mathrm{mL})$ from $E$.coli BL21 (DE3) degraded $50 \mu \mathrm{M} \mathrm{C}$ - $_{6} \mathrm{HSL}$ at $37{ }^{\circ} \mathrm{C}$ within $3 \mathrm{~h}$ (Fig. 2a). Meanwhile, the same results were detected by violacein generation bioassay of $C$. violaceum $\mathrm{CV} 026$ (Fig. 2b). Here, LcAiiK cells (without any treatment) were used to directly degrade $\mathrm{C}_{6}-\mathrm{HSL}$, and $L c$ AiiK cells did degrade $\mathrm{C}_{6}-\mathrm{HSL}$ (Fig. 2a). From this, we can speculate that AiiK was expressed and located at the outermost layer of $L c$ AiiK cells. Therefore, $L c$ AiiK exhibited

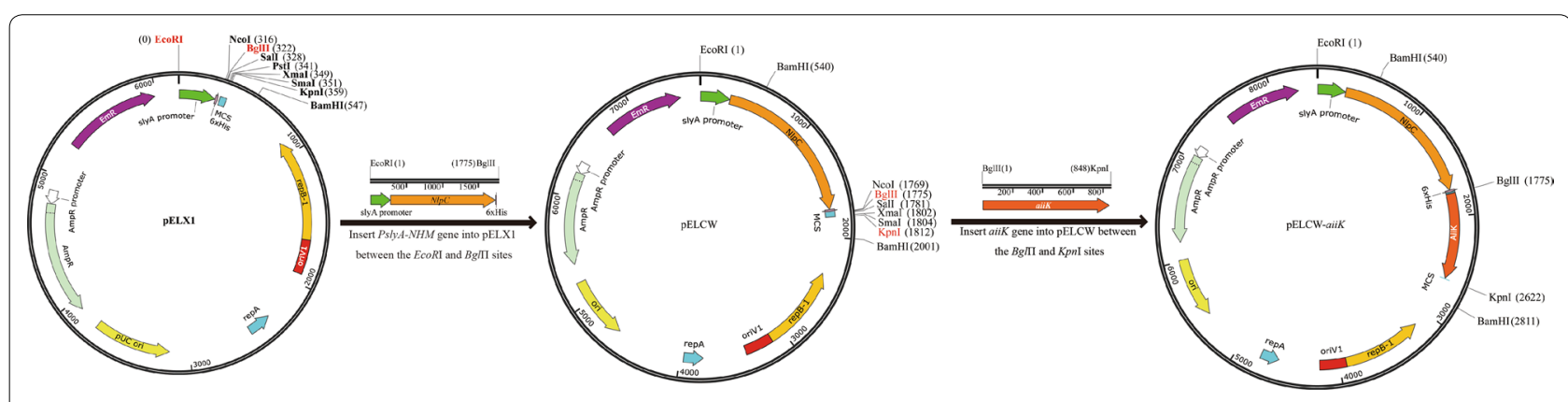

Fig. 1 Flow chart of construction of the cell wall-associated expression vectors pELCW and pELCW-aiik
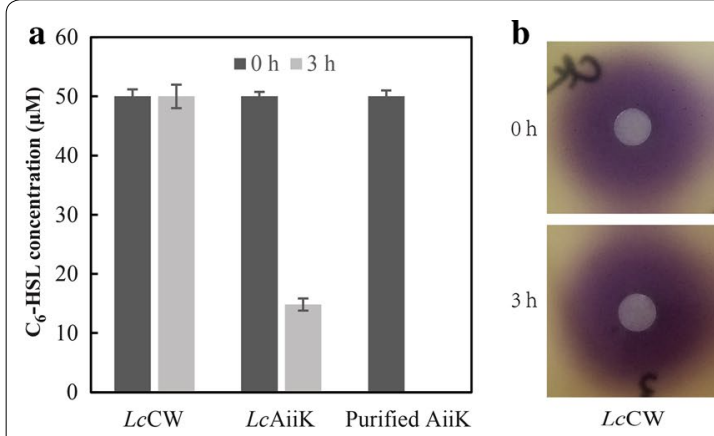

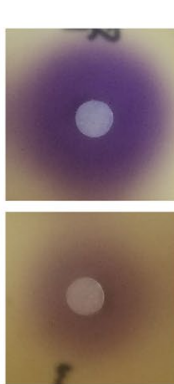

LcAiiK

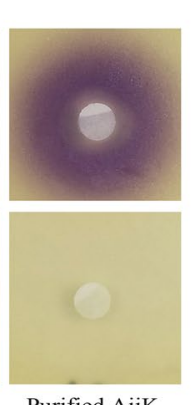

Purified AiiK

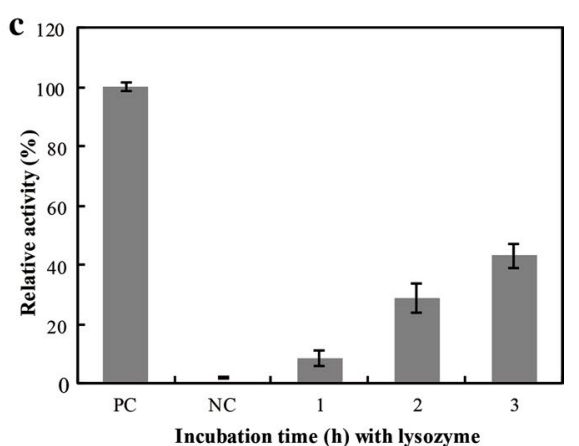

Fig. 2 a AHL lactonase activity of LCAiiK detected by HPLC (LCCW cells were used as negative control, purified AiiK was used as positive control). $\mathbf{b}$ AHL lactonase activity of LCAiiK detected by violacein generation of C. violaceum CV026 (LcCW cells were used as negative control, purified AiiK was used as positive control). c Localization assays of AiiK in LCAiiK, PC represents positive control and NC represents negative control. Data are shown as mean $\pm S D, n=3$ 
significant AHL lactonase activity, and the protein AiiK was expressed at the outermost layer of LcAiiK cells (Fig. 2a and b).

Although the protein AiiK was expressed at the outermost layer of $L c$ AiiK cells, it remained unclear whether AiiK was expressed at surface layer of $L c$ AiiK. The localization assays of AiiK revealed that AHL lactonase activity of supernatant increased with incubation time compared with negative control (Fig. 2c). The lysozyme can degrade peptidoglycan of cell wall and release surface layer proteins. Thus, AHL lactonase activity of supernatant increased significantly within the treatment of lysozyme, which indicated that AiiK was expressed at the surface layer of $L c$ AiiK.

\section{Characteristics of LCAiiK}

Many previous studies have reported that $\mathrm{C}_{6}$-HSL is a vital signal molecule mediating QS processes such as motility, haemolytic activity, extracellular proteolytic activity, and biofilm formation in A. hydrophila [6, 26, 31-33]. Thus, $\mathrm{C}_{6}-\mathrm{HSL}$ was used as substrate to detect AHL lactonase activity of $L c$ AiiK in our study. $L c$ AiiK $\left(\mathrm{OD}_{600}=0.5\right)$ degraded $24.13 \mu \mathrm{M}$ of $\mathrm{C}_{6}-\mathrm{HSL}$ at $2 \mathrm{~h}$,
$40.99 \mu \mathrm{M}$ of $\mathrm{C}_{6}-\mathrm{HSL}$ at $12 \mathrm{~h}$, and $46.63 \mu \mathrm{M}$ of $\mathrm{C}_{6}-\mathrm{HSL}$ at $24 \mathrm{~h}$ (Fig. $3 \mathrm{a}$ ). The optimal $\mathrm{OD}_{600}$ of $L c$ AiiK to degrade $\mathrm{C}_{6}$-HSL was determined at value of 1.0 (Fig. $3 \mathrm{~b}$ ). The optimal reaction temperature of $L c$ AiiK to degrade $\mathrm{C}_{6}$-HSL was $45{ }^{\circ} \mathrm{C}$ (Fig. 3c). The in vivo experiments showed that $\mathrm{Zn}^{2+}, \mathrm{Mg}^{2+}, \mathrm{Co}^{2+}$, and $\mathrm{Ni}^{2+}$ increased AHL lactonase activity of $L c$ AiiK, however, $\mathrm{Mn}^{2+}$ slightly decreased its activity (Fig. 3d). Moreover, the in vitro experiments revealed that $\mathrm{Mg}^{2+}$ and $\mathrm{Ni}^{2+}$ increased AHL lactonase activity of $L c$ AiiK, however, $\mathrm{Zn}^{2+}, \mathrm{Mn}^{2+}$, and $\mathrm{Co}^{2+}$ decreased its activity (Fig. $3 \mathrm{~d}$ ). Interestingly, $L c$ AiiK cultured in DMIF-MRS was found to exhibit higher AHL lactonase activity than that cultured in MRS from both in vivo and in vitro experiments (Fig. 3d). These characteristics provided the foundation and guiding significance for the practical use of $L c$ AiiK.

\section{Determination of plasmid stability}

The plasmid stability of pELCW-aiiK was measured by counting the colonies after continuous passage culture in MRS for 15 generations under the nonselective condition. The results revealed that plasmid stability of pELCWaiiK decreased slightly from $81.00 \%$ to $77.38 \%$ during the
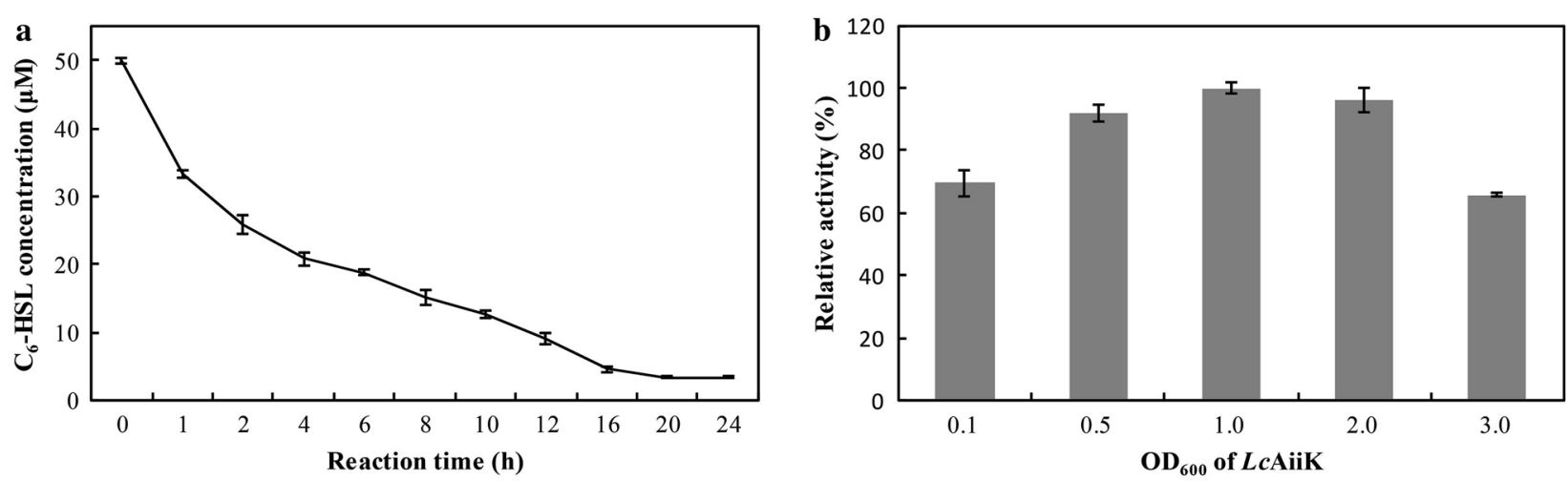

c

d
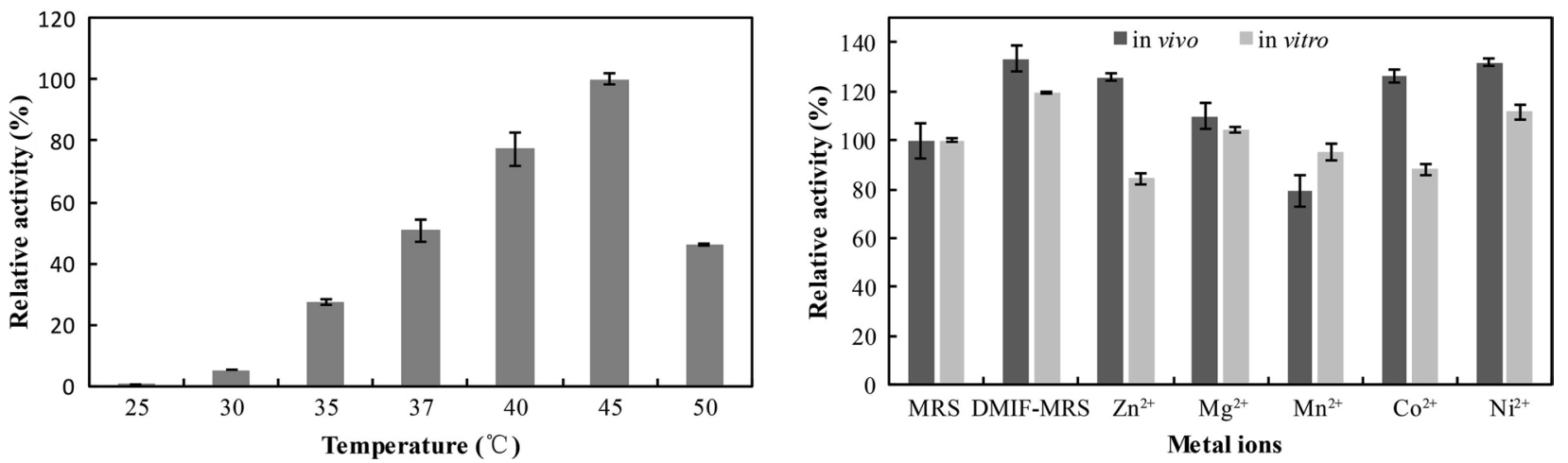

Fig. 3 Characteristics of LCAiiK. a $\mathrm{C}_{6}$-HSL degradation curve of LCAiiK within $24 \mathrm{~h}$. $\mathbf{b}$ Optimal $\mathrm{OD}_{600}$ of LCAiiK for degrading $\mathrm{C}_{6}$-HSL. c Optimal reaction temperature of $L C A i i K$. $\mathbf{d}$ Effect of divalent metal ions on AHL lactonase activity of $L C A i i K$ in vivo and vitro [reaction was performed with $L C A i i K$ cells $\left(\mathrm{OD}_{600}=0.5\right)$ at $37^{\circ} \mathrm{C}$ for $12 \mathrm{~h}$. Data are shown as mean $\pm \mathrm{SD}, \mathrm{n}=3$ 


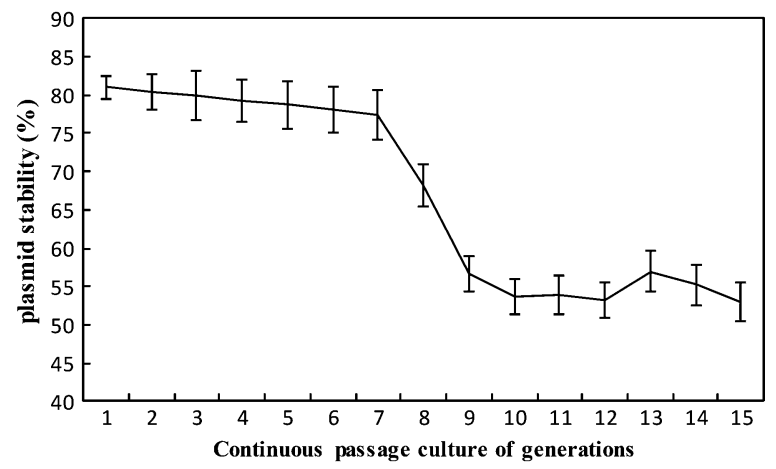

Fig. 4 pELCW-aiiK plasmid stability of LCAiiK during continuous passage culture in MRS for 15 generations under the nonselective condition. Data are shown as mean $\pm \mathrm{SD}, \mathrm{n}=3$

first 7 generations, then tobogganed to $56.69 \%$ at generation 9 , and finally remained stable from generation 10 to 15 with the value of $53.04 \%$ (Fig. 4). In short, over $50 \%$ of LcAiiK cells maintained plasmid pELCW-aiiK after 15 generations without erythrocin. From this result, we speculated that the $L c$ AiiK might maintain the QQ ability for a period which was sufficient for $L c$ AiiK cells to maintain the pELCW-aiiK plasmid while proliferating.

\section{LcAiiK's application in QQ on A. hydrophila}

$L c$ AiiK was found to quench the AHL-mediated QS processes of A. hydrophila AH-1 and AH-4 in this study (Fig. 5). LcAiiK significantly hampered the swimming motility of A. hydrophila AH-1 and AH-4, compared to $\mathrm{CK}$ and negative control (Fig. 5a). The inhibition ratio of swimming motility was dependent on the dose of LcAiiK (Fig. 5a). LcAiiK showed slight inhibition effect on haemolytic activity of $A$. hydrophila AH-1 and AH-4, compared to CK and negative control (Fig. 5b). LcAiiK $\left(\mathrm{OD}_{600}=0.4\right)$ reduced extracellular proteolytic activity of A. hydrophila AH-1 and AH-4 by $35.29 \%$ (Fig. 5c) and $42.01 \%$ (Fig. $5 \mathrm{~d}$ ) after co-culture, respectively, and $L c \mathrm{CW}$ (negative control) did not exhibit inhibition effect on that of A. hydrophila AH-1 (Fig. 5c) and AH-4 (Fig. 5d). Moreover, the increased application of $L c$ AiiK resulted in the obvious decrease in biofilm formation of $A$. hydrophila $\mathrm{AH}-1$ (Fig. 5e) and AH-4 (Fig. 5f), compared to CK and negative control. Furthermore, plate counting results indicated that planktonic cells of $A$. hydrophila $\mathrm{AH}-1$ and AH- 4 remained stable at the value of $10.1 \times 10^{7} \mathrm{cfu} / \mathrm{mL}$ (Fig. 5e) and $4.3 \times 10^{7} \mathrm{cfu} / \mathrm{mL}$ (Fig. 5f) after co-culture, respectively. And this reflected that $L c$ AiiK inhibited biofilm formation of $A$. hydrophila $\mathrm{AH}-1$ and $\mathrm{AH}-4$, but not kill them when co-culture. Therefore, these results demonstrated that $L c$ AiiK obviously attenuated the swimming motility, haemolytic activity, extracellular proteolytic activity, and biofilm formation of $A$. hydrophila AH-1 and AH-4.

\section{Discussion}

QS is a population-dependent behavior in bacteria for communicating with each other, which orchestrates expression of multiple genes triggered by signal molecules when external environment changes [8, 10, 34-38]. AHLs as important signal molecules mediating many QS processes were identified in multiple gram-negative bacterial species, and most bacteria were common pathogens existing in various environments [26]. Many studies have revealed that AHL-mediated QS was closely related to the pathogenicity, virulence factor production, and biofilm formation in gram-negative pathogens $[2$, $3]$. The acute hemorrhagic septicemia in fish and diarrhea even death in human caused by microbial infections were closely related to the AHL-mediated QS in various gram-negative pathogens, especially $A$. hydrophila, $A$. salmonicida, and $P$. aeruginosa $[4,5,39-42]$. However, the antibiotic therapy for these gram-negative pathogens will accelerate the emergence of drug-resistance. Thus, it is urgent to develop a promising strategy to inhibit or quench these processes of AHL-mediated QS [43-45]. Interfering or quenching $\mathrm{QS}$, known as $\mathrm{QQ}$, is becoming a prospective tactic for reducing the pathogenicity triggered by AHL-mediated QS [9, 17-20, 46, 47]. QQ enzymes are of great importance in inhibiting or attenuating pathogenicity. Therefore, the QQ enzymes can be widely applied as bio-control agents.

In this study, QQ enzyme AiiK was expressed at the surface layer of strain $L$. casei $\mathrm{MCJ} \Delta 1$. This is the first report that QQ enzyme was expressed in lactic acid bacteria Lactobacilli genus implemented by cell wallassociated constitutive expression vector pELCW-aiiK. Meanwhile, the cell wall-associated constitutive expression vector pELCW provides a genetic tool for DNA

\footnotetext{
(See figure on next page.)
}

Fig. 5 Effect of LCAiiK on the swimming motility, virulence factor production, and biofilm formation in A. hydrophila AH-1 and AH-4. a The swimming motility of $\mathrm{A}$. hydrophila $\mathrm{AH}-1$ and $\mathrm{AH}-4$. $\mathbf{b}$ The haemolytic activity of $\mathrm{A}$. hydrophila $\mathrm{AH}-1$ and $\mathrm{AH}-4$. c The extracellular proteolytic activity of A. hydrophila AH-1. d The extracellular proteolytic activity of A. hydrophila AH-4. e Biofilm formation (column chart) was detected by crystal violet staining, and planktonic cells (red line chart) were detected by plate counting of $\mathrm{A}$. hydrophila $\mathrm{AH}-1$. $\mathbf{f}$ Biofilm formation (column chart) was detected by crystal violet staining, and planktonic cells (red line chart) were detected by plate counting of A. hydrophila AH-4. Data are shown as mean $\pm S D, n=3$. A t test was performed for testing differences between groups, and the ** and * indicate $P<0.01$ and $P<0.05$, respectively 
$\mathbf{a}$

AH-1
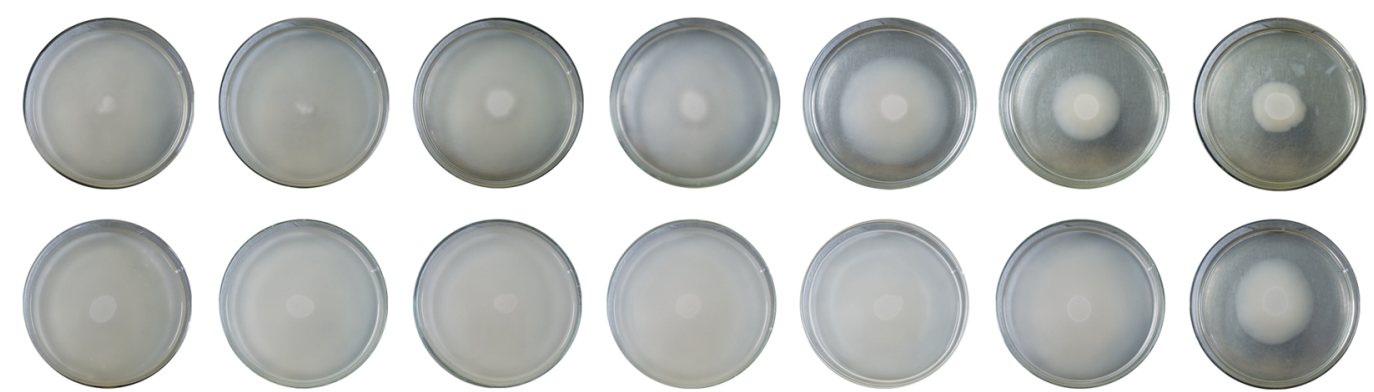

AH-4
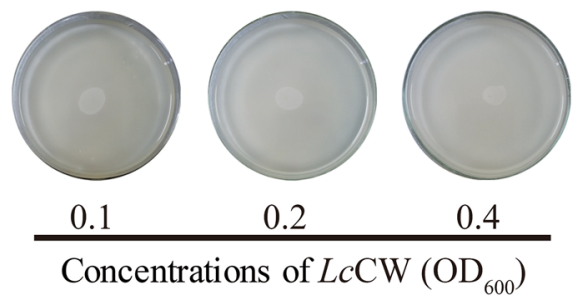

b

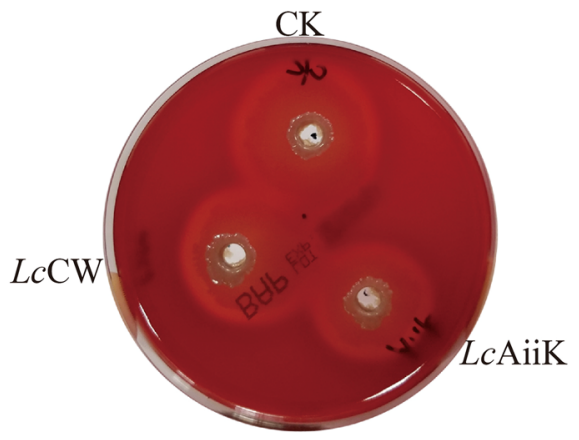

AH-1

c
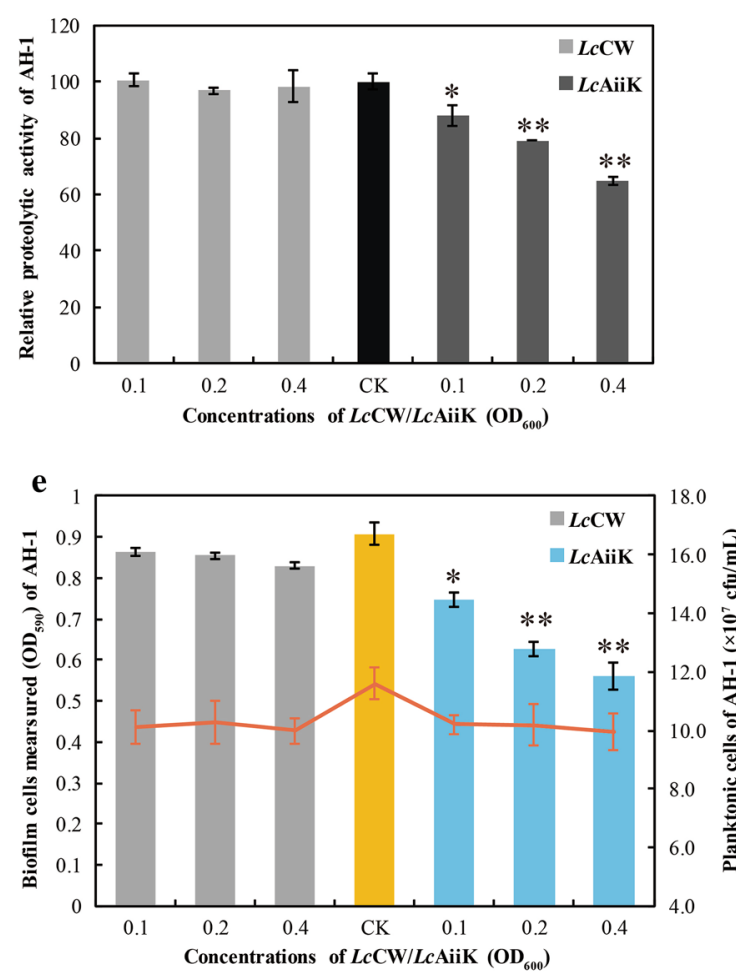

CK
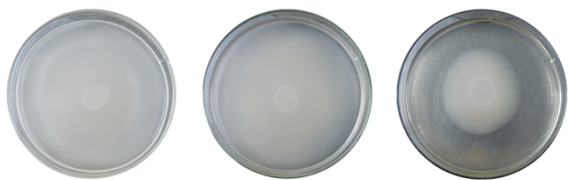

0.2

$\frac{0.4}{\left(\mathrm{OD}_{600}\right)}$

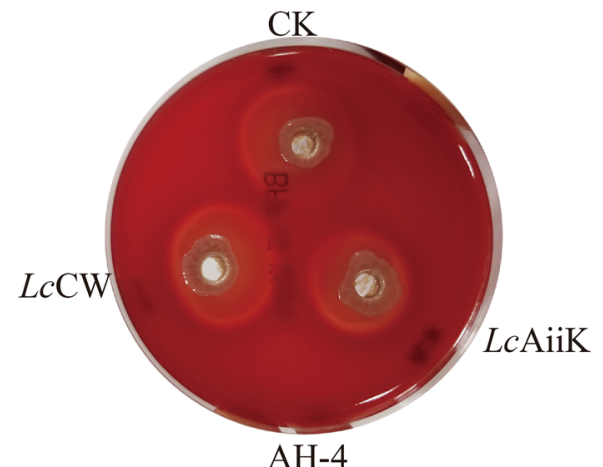

d

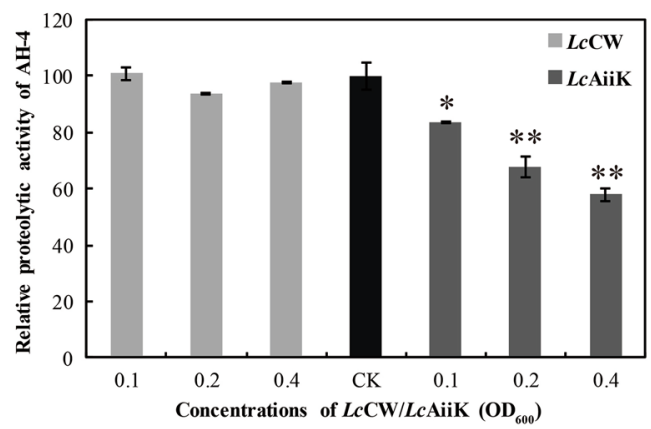

f

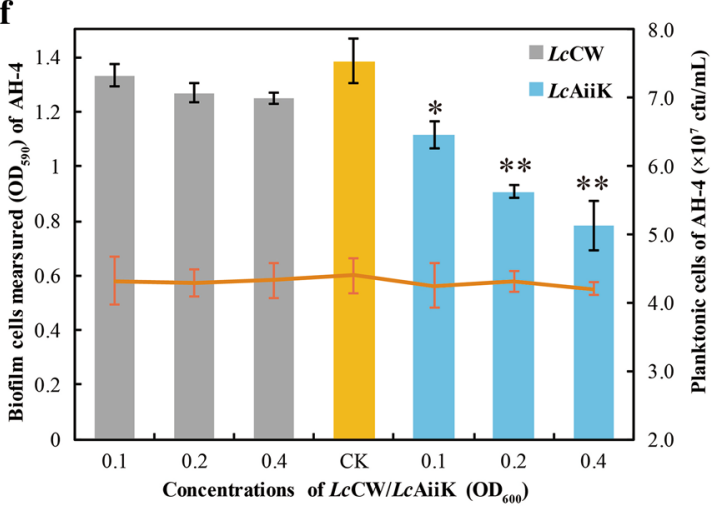


clone and a new perspective for heterologous gene expression at the surface layer of strain $L$. case $\mathrm{MCJ} \Delta 1$. Many studies have reported that QQ enzymes were heterologously expressed by E. coli, but few works were done by utilizing other expression systems. So far, Chen et al. used the vector pPIC9 to express recombinant AiiA $A_{B 546}$ in Pichia pastoris [21], and Zhang et al. applied B. brevis expression system to express MomL [26]. These two expression systems produced secreted proteins and the application of the proteins required prior purification steps. Herein, we utilized vector pELCW-aiiK to express the AiiK which anchored at the surface layer of $L c$ AiiK, making $L c$ AiiK cells can be applied directly without any processing steps.

Considering the characteristics of $L c$ AiiK, our results revealed that $L c$ AiiK maintained the same optimal reaction temperature with purified AiiK at $45{ }^{\circ} \mathrm{C}$ [18]. The effect of divalent metal ions on $L c$ AiiK was slighter than that on purified AiiK [18]. Based on this finding, it could be speculated that $L c$ AiiK is less affected by external environment (such as divalent metal ions) than purified AiiK. AHL lactonase activity of LcAiiK increased from $100.00 \%$ (day 1) to $192.10 \%$ (day 3), then dropped slowly to $155.87 \%$ (day 6) (Additional file 1: Fig. S2). However, the live $L c$ AiiK cells were decreased quickly from $7.4 \times 10^{7} \mathrm{cfu} / \mathrm{mL}$ (day 1) to $7.8 \times 10^{6} \mathrm{cfu} / \mathrm{mL}$ (day 6) when $L c$ AiiK was stored in $10 \mathrm{mM}$ PBS at $4{ }^{\circ} \mathrm{C}$ (Additional file 1: Fig. S2). Based on this result, we speculated that the cell wall lysis released the AiiK from surface layer and increased AHL lactonase activity (Additional file 1: Fig. S2). LcAiiK could maintain $155.87 \%$ AHL lactonase activity after 6 -day storage at $4{ }^{\circ} \mathrm{C}$ (Additional file 1: Fig. S2), while purified AiiK could only retain 20\% AHL lactonase activity after 12 -h storage at $37^{\circ} \mathrm{C}$ [18]. This finding implied that $L c$ AiiK endows higher stability compared to that of purified AiiK, which solves the drawback of instability of purified AiiK. The anchored AiiK at the surface layer of $L c$ AiiK maintained good stability to sustainably degrade AHLs (Additional file 1: Fig. S2), which can be more useful in factual environment. Moreover, LcAiiK could retain over $50 \%$ plasmid stability of pELCW-aiiK within 15 generations, reflecting that plasmid pELCWaiiK can exist in cells for a long time. Our previous study reported that AiiK could degrade multiple AHLs including $\mathrm{C}_{6}$-HSL, 3-Oxo- $\mathrm{C}_{6}-\mathrm{HSL}, \mathrm{C}_{10}-\mathrm{HSL}$, and $\mathrm{C}_{14}$ - $\mathrm{HSL}$ [18]. Therefore, these characteristics of $L c$ AiiK lay a solid foundation for its application in the field of QQ.

Herein, we verified the QQ ability of $L c$ AiiK against $A$. hydrophila by co-culture. The reason why $A$. hydrophila was selected as the target strain was that this bacterium is an emerging gram-negative opportunistic pathogen that can cause various serious symptoms in fish, crabs, shrimps, and even humans [4, 6, 7]. Many studies have reported that the pathogenicity and human infections depend on the AHL-mediated QS in A. hydrophila $[6,13]$. The main AHL signal molecules are $\mathrm{C}_{6}$-HSL and $N$-butanoyl-L-homoserine lactone $\left(\mathrm{C}_{4}-\mathrm{HSL}\right)$ in $A$. hydrophila [6, 13, 31-33]. Besides, the biofilm formation of $A$. hydrophila was highly associated with multiple antibiotics resistance, making the diseases or infections difficult to be cured [14]. In this study, the AiiK was expressed at the surface layer of LcAiiK with AHL lactonase activity (Fig. 2). LcAiiK exhibited an obvious QQ ability against $A$. hydrophila $\mathrm{AH}-1$ and $\mathrm{AH}-4$ by degrading their signal molecule $\mathrm{C}_{6}$-HSL (Figs. 5 and Fig. 6). Meanwhile, LcAiiK did not kill the planktonic cells of A. hydrophila $\mathrm{AH}-1$ and $\mathrm{AH}-4$ at co-culture condition, implying that $L c$ AiiK did not accelerate the emergence of drug-resistance (Fig. 5e and f). Therefore, this might be a promising anti-pathogenic strategy to control pathogenic bacteria and to prevent antibiotic resistance. It was reported that recombinant strain $B b M o m L$ significantly reduced the secretion of pathogenic factors and the pathogenicity of $P$. carotovorum subsp. carotovorum and P. aeruginosa PAO1 [26]. Chen et al. expressed QQ enzyme $\mathrm{AiiA}_{\mathrm{B} 546}$ by pPIC9/P. pastoris expression system, and $\mathrm{AiiA}_{\mathrm{B} 546}$ decreased the mortality rate and delayed the mortality time of fish by co-injecting $A$. hydrophila and AiiA $_{\mathrm{B} 546}$ into common carp [21]. In our study, the AiiK was expressed at the surface layer of $L c$ AiiK. Therefore, LcAiiK cells harboring the AiiK protein on their cell walls were co-cultured directly with $A$. hydrophila AH-1 and $\mathrm{AH}-4$ to quench their QS processes. This strategy is easy to apply as it only involves cultivation of $L c$ AiiK cells without purification steps. Zhou et al. reported that Bacillus sp. QSI-1 significantly decreased haemolytic and protease activity of $A$. hydrophila YJ-1 [48], which was consistent with our present results.

Interestingly, LcAiiK was found to exhibit higher AHL lactonase activity when it was cultured in DMIF-MRS than in MRS (Fig. 3d). Correspondingly, we speculated that the AHL lactonase activity of LcAiiK could be improved by optimizing the culture formula (such as divalent metal ions), and this speculation deserves further study. As for safety issue, L. casei is one kind of lactic acid bacteria which is commonly considered as an environment friendly probiotic. Furthermore, many studies have demonstrated that the L. casei is an important probiotic [49-52]. L. casei inhibited the growth of Streptococcus mutans in caries prevention [49], decreased the relative abundance of intestinal Escherichia-Shigella in suckling rabbit [50], and attenuated the biofilm development of Candida albicans [51]. The health-promoting feature of $L$. casei was documented by Hill et al., reporting the potentials of $L$. case $i$ in the treatment or prevention of a variety of diseases [52]. Therefore, the probiotic 


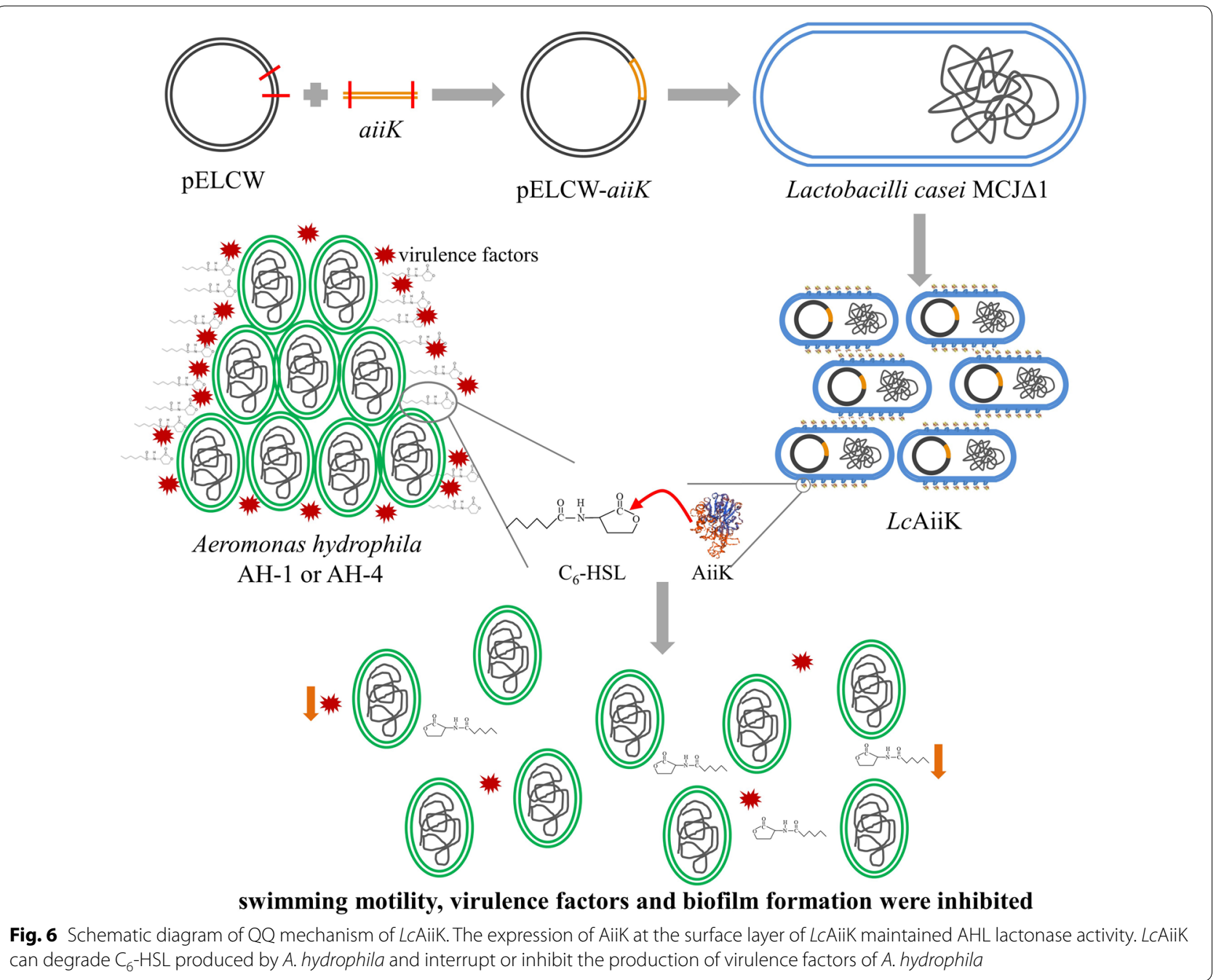

capabilities of $L$. casei made $L c$ AiiK safe to be applied. These probiotic capabilities also expanded the application range of $L c$ AiiK, which suggested that $L c$ AiiK could not only be used as probiotic, but also be exploited as an anti-pathogenic drug or a bio-control agent against the AHL-mediated QS pathogenic bacteria.

\section{Conclusions}

AHL lactonase AiiK is firstly expressed at the surface layer of $L$. casei $\mathrm{MCJ} \Delta 1$ via a cell wall-associated constitutive expression vector pELCW-aiiK. LcAiiK exhibited considerable AHL lactonase activity and displayed obvious QQ ability against $A$. hydrophila $\mathrm{AH}-1$ and $\mathrm{AH}-4$ by attenuating their swimming motility, virulence factor production, and biofilm formation instead of killing them. Therefore, the $L c$ AiiK can be developed as an anti-pathogenic agent to control AHL-mediated QS pathogenic bacteria and prevent the emergence of antibiotic resistance.

\section{Supplementary information}

Supplementary information accompanies this paper at https://doi. org/10.1186/s12934-020-01448-4.

Additional file 1. Text 1. $16 \mathrm{~S}$ rDNA sequence of $A$. hydrophila AH-1. Text 2. $16 \mathrm{~S}$ rDNA sequence of $A$. hydrophila AH-4. Table S1. Amplification composition and condition of SOE-PCR. Fig. S1. Agarose gel electrophoresis of SOE-PCR product $P_{\text {slyA }}-\mathrm{NHM}$ gene. Fig. S2. AHL lactonase activity and live cells of LCAiik after storage at $4^{\circ} \mathrm{C}$.

\section{Acknowledgements}

Not applicable.

\section{Authors' contributions}

SMZ, NP, and YXL conceived and supervised the study. WWD designed the experiments, performed the main experiments, acquired and analysed the data, and drafted the manuscript. YYC, ZLX, BF, QTC, YXC and ZYR performed partial experiments and contributed to the manuscript. All authors reviewed the manuscript and provided meaningful intellectual contributions to the study. All authors read and approved the final manuscript. 


\section{Funding}

This study was financially supported by Grant 2662018JC016 of the Fundamental Research Funds for the Central Universities.

\section{Availability of data and materials}

All data generated or analyzed during this study are included in this published article and its Additional file.

\section{Ethics approval and consent to participate}

Not applicable.

\section{Consent for publication}

Not applicable.

\section{Competing interests}

The authors declare that they have no competing interests.

\section{Author details}

1 State Key Laboratory of Agricultural Microbiology and College of Life Science and Technology, Huazhong Agricultural University, Wuhan 430070, China. ${ }^{2}$ Institute of Agricultural Resources and Regional Planning, CAAS, Beijing 100081, China.

Received: 21 November 2019 Accepted: 25 September 2020 Published online: 07 October 2020

\section{References}

1. Defoirdt T. Implications of ecological Niche differentiation in marine bacteria for microbial management in aquaculture to prevent bacterial disease. PLoS Pathog. 2016;12:e1005843.

2. Swift S, Karlyshev AV, Fish L, Durant EL, Winson MK, Chhabra SR, Williams P, Macintyre S, Stewart GSAB. Quorum sensing in Aeromonas hydrophila and Aeromonas salmonicida identification of the LuxRI homologs AhyRI and $\mathrm{AsaRI}$ and their cognate $\mathrm{N}$-acylhomoserine lactone signal molecul. J Bacteriol. 1997;179:5271-81.

3. Lynch MJ, Swift S, Kirke DF, Keevil CW, Dodd CER, Williams P. The regulation of biofilm development by quorum sensing in Aeromonas hydrophila. Environ Microbiol. 2002;4:18-28.

4. Vivas J, Carracedo B, Riano J, Razquin BE, Lopez-Fierro P, Acosta F, Naharro G, Villena AJ. Behavior of an Aeromonas hydrophila aroA live vaccine in water microcosms. Appl Environ Microbiol. 2004;70:2702-8.

5. Agger WA, Mccormick JD, Gurwith MJ. Clinical and microbiological features of Aeromonas hydrophila-associated diarrhea. J Cli Microbiol. 1985:21:909-13.

6. Jahid IK, Mizan MF, Ha AJ, Ha SD. Effect of salinity and incubation time of planktonic cells on biofilm formation, motility, exoprotease production, and quorum sensing of Aeromonas hydrophila. Food Microbiol. 2015:49:142-51.

7. Chen B, Peng M, Tong W, Zhang Q, Song Z. The Quorum Quenching Bacterium Bacillus licheniformis T-1 Protects Zebrafish against Aeromonas hydrophila Infection. Probiotics Antimicrob Proteins. 2019. https://doi. org/10.1007/s12602-018-9495-7.

8. Eickhoff MJ, Bassler BL. SnapShot: bacterial Quorum Sensing. Cell. 2018;174(1328-1328):e1321.

9. See-Too WS, Convey P, Pearce DA, Chan KG. Characterization of a novel $\mathrm{N}$-acylhomoserine lactonase, AidP, from Antarctic Planococcus sp. Microb Cell Fact. 2018:17:179.

10. Fetzner S. Quorum quenching enzymes. J Biotechnol. 2015;201:2-14.

11. Chhabra SR, Harty C, Hooi DSW, Daykin M, Williams P, Telford G, Pritchard DI, Bycroft BW. Synthetic analogues of the bacterial signal (Quorum Sensing) molecule $\mathrm{N}$-(3-Oxododecanoyl)-I-homoserine lactone as immune modulators. J Med Chem. 2003:46:97-104.

12. Atkinson S, Williams P. Quorum sensing and social networking in the microbial world. J R Soc Interface. 2009;6:959-78.

13. Sha J, Pillai L, Fadl AA, Galindo CL, Erova TE, Chopra AK. The type III secretion system and cytotoxic enterotoxin alter the virulence of Aeromonas hydrophila. Infect Immun. 2005;73:6446-57.
14. Defoirdt T, Thanh LD, Van Delsen B, De Schryver P, Sorgeloos P, Boon N, Bossier P. N-acylhomoserine lactone-degrading Bacillus strains isolated from aquaculture animals. Aquaculture. 2011:311:258-60.

15. Chen F, Gao Y, Chen X, Yu Z, Li X. Quorum quenching enzymes and their application in degrading signal molecules to block quorum sensingdependent infection. Int J Mol Sci. 2013;14:17477-500.

16. Dickey SW, Cheung GYC, Otto M. Different drugs for bad bugs: antivirulence strategies in the age of antibiotic resistance. Nat Rev Drug Discov. 2017:16:457-71.

17. Tang K, Su Y, Brackman G, Cui F, Zhang Y, Shi X, Coenye T, Zhang XH MomL, a novel marine-derived $\mathrm{N}$-acyl homoserine lactonase from Muricauda olearia. Appl Environ Microbiol. 2015;81:774-82.

18. Dong W, Zhu J, Guo X, Kong D, Zhang Q, Zhou Y, Liu X, Zhao S, Ruan Z. Characterization of AiiK, an AHL lactonase, from Kurthia huakui LAM0618(T) and its application in quorum quenching on Pseudomonas aeruginosa PAO1. Sci Rep. 2018;8:6013.

19. Cai X, Yu M, Shan H, Tian X, Zheng Y, Xue C, Zhang XH. Characterization of a Novel N-Acylhomoserine Lactonase RmmL from Ruegeria mobilis YJ3. Mar Drugs. 2018;16:370.

20. Zhang B, Zhuang XY, Guo LY, Mclean RJC, Chu Wh. Recombinant N-acyl homoserine lactone-lactonase $\mathrm{Aii}_{\mathrm{QSI}-1}$ attenuates Aeromonas hydrophila virulence dactors, biofilm formation and reduces mortality in Crucian Carp. Mar Drugs. 2019;17:499.

21. Chen RD, Zhou ZG, Cao YN, Bai YG, Yao B. High yield expression of an AHLlactonase from Bacillus sp. B546 in Pichia pastoris and its application to reduce Aeromonas hydrophila mortality in aquaculture. Microb Cell Fact. 2010;9:39.

22. Dong $Y H$, Xu JL, Li XZ, Zhang LH. AiiA, an enzyme that inactivates the acylhomoserine lactone quorum-sensing signal and attenuates the virulence of Erwinia carotovora. Proc Natl Acad Sci. 2000;97:3526-31.

23. Wang WZ, Morohoshi T, Ikenoya M, Someya N, Ikeda T. AiiM, a novel class of $\mathrm{N}$-acylhomoserine lactonase from the leaf-associated bacterium Microbacterium testaceum. Appl Environ Microbiol. 2010;76:2524-30.

24. Lin L, Xu X, Zheng Y, Zhang C. Effects of AttM lactonase on the pathogenicity of Streptomyces scabies. Lett Appl Microbiol. 2018;67:270-7.

25. Torres M, Uroz S, Salto R, Fauchery L, Quesada E, Llamas I. HqiA, a novel quorum-quenching enzyme which expands the AHL lactonase family. Sci Rep. 2017;7:943.

26. Zhang J, Wang J, Feng T, Du R, Tian X, Wang Y, Zhang XH. Heterologous expression of the marine-derived quorum quenching enzyme MomL can expand the antibacterial spectrum of Bacillus brevis. Mar Drugs. 2019;17:128.

27. Chen Z, Lin J, Ma C, Zhao S, She Q, Liang Y. Characterization of pMC11, a plasmid with dual origins of replication isolated from Lactobacillus casei $\mathrm{MCJ}$ and construction of shuttle vectors with each replicon. Appl Microbiol Biotechnol. 2014;98:5977-89.

28. Heckman KL, Pease LR. Gene splicing and mutagenesis by PCR-driven overlap extension. Nat Protoc. 2007;2:924-32.

29. Chu W, Zhou S, Zhu W, Zhuang X. Quorum quenching bacteria Bacillus sp. QSI-1 protect zebrafish (Danio rerio) from Aeromonas hydrophila infection. Sci Rep. 2014;4:5446.

30. Patel B, Kumari S, Banerjee R, Samanta M, Das S. Disruption of the quorum sensing regulated pathogenic traits of the biofilm-forming fish pathogen Aeromonas hydrophila by tannic acid, a potent quorum quencher. Biofouling. 2017:33:580-90.

31. Khajanchi BK, Sha J, Kozlova EV, Erova TE, Suarez G, Sierra JC, Popov VL, Horneman AJ, Chopra AK. N-acylhomoserine lactones involved in quorum sensing control the type $\mathrm{VI}$ secretion system, biofilm formation, protease production, and in vivo virulence in a clinical isolate of Aeromonas hydrophila. Microbiology. 2009;155:3518-31.

32. Jahid IK, Lee NY, Kim A, Ha SD. Influence of glucose concentrations on biofilm formation, motility, exoprotease production, and quorum sensing in Aeromonas hydrophila. J Food Prot. 2013;76:239-47.

33. Zhou S, Zhang A, Yin H, Chu W. Bacillus sp. QSI-1 modulate quorum sensing signals reduce Aeromonas hydrophila level and alter gut microbial community structure in fish. Front Cell Infect Microbiol. 2016;6:184

34. Davies DG, Parsek MR, Pearson JP, Iglewski BH, Costerton JW, Greenberg EP. The involvement of cell-to-cell signals in the development of a bacterial biofilm. Science. 1998;280:295-8.

35. Rakoff-Nahoum S, Foster KR, Comstock LE. The evolution of cooperation within the gut microbiota. Nature. 2016;533:255-9. 
36. Pader V, Hakim S, Painter KL, Wigneshweraraj S, Clarke TB, Edwards AM. Staphylococcus aureus inactivates daptomycin by releasing membrane phospholipids. Nat Microbiol. 2016;2:16194.

37. Bandyopadhaya A, Tsurumi A, Maura D, Jeffrey KL, Rahme LG. A quorumsensing signal promotes host tolerance training through HDAC1-mediated epigenetic reprogramming. Nat Microbiol. 2016;1:16174.

38. Lee JH, Lee J. Indole as an intercellular signal in microbial communities. FEMS Microbiol Rev. 2010;34:426-44.

39. Bjarnsholt $T$, Jensen $P O$, Burmolle $M$, Hentzer $M$, Haagensen JA, Hougen HP, Calum H, Madsen KG, Moser C, Molin S, Hoiby N, Givskov M. Pseudomonas aeruginosa tolerance to tobramycin, hydrogen peroxide and polymorphonuclear leukocytes is quorum-sensing dependent. Microbiology. 2005;151:373-83.

40. Dou Y, Song F, Guo F, Zhou Z, Zhu C, Xiang J, Huan J. Acinetobacter baumannii quorum-sensing signalling molecule induces the expression of drug-resistance genes. Mol Med Rep. 2017;15:4061-8.

41. Koch G, Nadal-Jimenez P, Reis CR, Muntendam R, Bokhove M, Melillo E, Dijkstra BW, Cool RH, Quax WJ. Reducing virulence of the human pathogen Burkholderia by altering the substrate specificity of the quorumquenching acylase PvdQ. Proc Natl Acad Sci. 2014;111(4):1568-73.

42. Sokol PA, Sajjan U, Visser MB, Gingues S, Forstner J, Kooi C. The CepIR quorum-sensing system contributes to the virulence of Burkholderia cenocepacia respiratory infections. Microbiology. 2003;149:3649-58.

43. Harms A, Maisonneuve E, Gerdes K. Mechanisms of bacterial persistence during stress and antibiotic exposure. Science. 2016;354:aaf4268.

44. Alekshun MN, Levy SB. Molecular mechanisms of antibacterial multidrug resistance. Cell. 2007;128:1037-50.

45. Defoirdt T, Sorgeloos P, Bossier P. Alternatives to antibiotics for the control of bacterial disease in aquaculture. Curr Opin Microbiol. 2011;14:251-8.
46. Clatworthy AE, Pierson E, Hung DT. Targeting virulence: a new paradigm for antimicrobial therapy. Nat Chem Biol. 2007;3:541-8.

47. Gupta K, Daroch P, Harjai K, Chhibber S. Parallels among natural and synthetically modified quorum-quenching strategies as convoy to future therapy. Microbiology. 2019. https://doi.org/10.1099/mic.0.000826.

48. Zhou S, Yu Z, Chu W. Effect of quorum-quenching bacterium Bacillus sp QSI-1 on protein profiles and extracellular enzymatic activities of Aeromonas hydrophila YJ-1. BMC Microbiol. 2019;19:135.

49. Lin $X$, Chen $X$, Tu Y, Wang S, Chen H. Effect of Probiotic Lactobacilli on the Growth of Streptococcus mutans and multispecies biofilms isolated from children with active caries. Med Sci Monit. 2017;23:4175-81.

50. Shen XM, Cui HX, Chen B, Xu XR. Orally administered Lactobacillus casei exhibited several probiotic properties in artificially suckling rabbits. AsianAustralas J Anim Sci. 2019. https://doi.org/10.5713/ajas.18.0973.

51. Matsubara VH, Wang Y, Bandara HM, Mayer MP, Samaranayake LP. Probiotic lactobacilli inhibit early stages of Candida albicans biofilm development by reducing their growth, cell adhesion, and filamentation. Appl Microbiol Biotechnol. 2016;100:6415-26.

52. Hill D, Sugrue I, Tobin C, Hill C, Stanton C, Ross RP. The Lactobacillus casei group: history and health related applications. Front Microbiol. 2018;9:2107.

\section{Publisher's Note}

Springer Nature remains neutral with regard to jurisdictional claims in published maps and institutional affiliations.
Ready to submit your research? Choose BMC and benefit from:

- fast, convenient online submission

- thorough peer review by experienced researchers in your field

- rapid publication on acceptance

- support for research data, including large and complex data types

- gold Open Access which fosters wider collaboration and increased citations

- maximum visibility for your research: over 100M website views per year

At BMC, research is always in progress.

Learn more biomedcentral.com/submissions 